\title{
Digital Payment System Analysis of Buying Decision in Indonesia
}

\author{
Nikma YUCHA ${ }^{1}$, Setiawan SETIAWAN ${ }^{2}$, Ninnasi MUTTAQIIN ${ }^{3}$, Ratna EKASARI ${ }^{4}$, Kemal Farouq MAULADI $^{5}$
}

Received: July 25, 2020 Revised: August 23, 2020 Accepted: August 28, 2020

\begin{abstract}
This study aims to analyze the changes in purchasing decisions in conducting transactions using cash and digital payment systems. Cash payment systems are very different from digital payments because they no longer use banks as intermediaries for transactions. The scope of this study is to determine the differences that take place with purchasing decisions using digital payment systems with OVO Indonesia smart applications. By using the paired T-test sample test method and testing the regression class assumptions, it is expected we will document the comparison between cash and digital payment systems as regards changes in consumers' buying interest behavior towards goods. Data is obtained by purposive sampling using special characteristics for smart application users. The results show that digital payments are developing very quickly, but cash payments still dominate due to the unavailability of complete facilities and infrastructure to support digital payment systems other than in cities. This study illustrates that digital payments have not been able to completely change consumer buying behavior in large numbers, but the main finding in this study is an increase in the percentage of digital payment usage to the online market, due to the many conveniences provided in OVO smart applications.
\end{abstract}

Keywords: Cash Payment, Digital Payment, Buying Decision, OVO Indonesia

JEL Classification Code: B26, D53, G21, G23, P4

\section{Introduction}

The development of digital technology is very rapid, causing changes in the mindset and habits of people in the world. The main component of sustainable development is the ability of local communities to find, define, and prioritize their own problems, and to access digital technology support to develop and implement appropriate solutions (Eitzel et al., 2018). Every company tries hard to manage its business

${ }^{1}$ First Author and Corresponding Author. Lecturer, Faculty of Economics and Business, Universitas Maarif Hasyim Latif, Indonesia [Postal Address: Jalan Raya Ngelom Megare, Sidoarjo, Jawa Timur, 61257, Indonesia]

Email: doni_arif@dosen.umaha.ac.id ; nikma@dosen.umaha.ac.id

${ }^{2}$ Lecturer, Faculty of Economics and Business, Universitas Maarif Hasyim Latif, Indonesia. Email: setiawan@dosen.umaha.ac.id

${ }^{3}$ Lecturer, Faculty of Economics and Business, Universitas Nahdlatul Ulama Surabaya, Indonesia. Email:m.ninnasi@unusa.ac.id

${ }^{4}$ Lecturer, Faculty of Economics and Business, Universitas Maarif Hasyim Latif, Indonesia. Email: ratna_ekasari@dosen.umaha.ac.id ${ }^{5}$ Lecturer, Faculty of Engineering, Universitas Islam Lamongan, Indonesia. Email: kemalfarouq@unisla.ac.id

(c) Copyright: The Author(s)

This is an Open Access article distributed under the terms of the Creative Commons Attribution Non-Commercial License (https://creativecommons.org/licenses/by-nc/4.0/) which permits unrestricted non-commercial use, distribution, and reproduction in any medium, provided the original work is properly cited. to be successful. The business market is turning to digitalbased businesses to sell products and make digital payments as a means of buying and selling transactions (Halik at al., 2020). Furthermore, the late 21st century has witnessed revolutionary growth in the information technology management and information system infrastructure networks (ARIF et al., 2020). Cash payment systems have become a habit and have been for a long time. Payment for retailed financial services is performed on a daily basis and is the financial services with the least regulated feature (Nguyen et al., 2020). In recent decades, traditional trading services with a cash payment system have been widely adopted by companies in the car, electronics, and technology industries to retain old customers and promote sales of new products (Cao et al., 2020).

Advances in information technology in the digital field led many applicators to create opportunities for digital payment services for ease of payment in various sectors. The development of the Internet and mobile phones has led to a profound transformation of the habits and preferences of consumers, who started using digital media to share information about themselves and communicate with companies, shop online and use new internet services (Alkhowaiter, 2020). Indonesia is the 5th largest country in the number of Internet users in the world and opens 
opportunities for the development of digital payment technology in the future; this is influenced by people's needs for the Internet, especially Internet users of cellular phones. Mobile communication technologies have a major impact on day-to-day life. Recently, several significant studies examined the effect of mobile technologies on the digital divide in the developed countries (Puspitasari \& Ishii, 2016).

Cellular usage provides a lot of convenience in transactions so that there is plenty of access for customers. With the trend in the transformation of Internet users in the digital era, which is increasingly being utilized by business platforms in Indonesia for e-commerce as a place to conduct online trading and supported by many cash and digital payment systems. The mode of payment that is offered to customers is important for a retailer's marketing and financial objectives and has direct implications for a firm's profitability (Grüschow et al., 2016).

Bank Indonesia estimates there are 24.7 million people who shop online, and the value of online shopping transactions is predicted to reach 156 trillion rupiahs in 2019 and continues to increase every year. The online shopping trend has opened the way to a digital payment method in Indonesia called Financial Technology (FinTech) to facilitate transactions. In other research (Palmié et al., 2020), FinTech explains how the ecosystem work around which disruptive innovations emerge and affect established industries. The well-established industry associated with this research is the cash payment system conducted by banks. One form of FinTech that is becoming a trend now is mobile payment. Mobile-based payment systems affect the lives of people around the world in more ways than other innovations in human history to become an integral part of 21st-century society (Patil et al., 2020).

In 2012, mobile payment services began to diversify, the banking industry and developers began making applications in the form of digital payments, and in 2017 one began to emerge - OVO (Visionet International Company). The use of digital payment transaction instruments in Indonesia has been growing very rapidly every year. The large number of consumers have paid with FinTech, supported by surging transaction volumes and the significant value of digital payment transactions since 2012; there have been 145 million electronic money transactions at FinTech (see Table 1).

Although users of digital payments through the FinTech application are increasing in Indonesia, in general, the use of cash payments still dominates, because Indonesians do not yet know and understand the ease and benefits of using electronic money, and there are still many people in areas that have not been reached by the Internet and other network facilities. FinTech appears as a "buzz word" or hype, especially in the press, as if it was an important phenomenon that should be observed by practitioners linked to the financial industry, information technology (IT) and innovation (incubators, venture capital, angels, among others) (Milian et al., 2019).
Table 1: Total volume of transactions and digital payments 2012-2019 Bank Indonesia

\begin{tabular}{|l|c|c|}
\hline Years & $\begin{array}{c}\text { Transaction } \\
\text { Volume }\end{array}$ & Nominal \\
\hline 2012 & 100.623 .916 & $\operatorname{Rp~} 1.971 .550$ \\
\hline 2013 & 137.900 .779 & $\operatorname{Rp~} 2.907 .432$ \\
\hline 2014 & 203.369 .990 & $\operatorname{Rp~3.319.556~}$ \\
\hline 2015 & 535.579 .528 & $\operatorname{Rp~5.283.018~}$ \\
\hline 2016 & 683.133 .352 & $\operatorname{Rp~} 7.063 .689$ \\
\hline 2017 & 943.319 .933 & $\operatorname{Rp~12.375.469~}$ \\
\hline 2018 & 2.922 .698 .905 & $\operatorname{Rp~47.198.616~}$ \\
\hline 2019 & 5.226 .699 .919 & $\operatorname{Rp~145.165.468~}$ \\
\hline
\end{tabular}

In Indonesia, the national movement for digital payments has been launched with transactions throughout the economic activity; therefore many government banks and national private banks have been appointed to participate in providing digital payment applications. Therefore, this study aims to find out and test the following hypotheses. H1: There was a change in purchasing decisions after the digital payment system was introduced. H0: There was no change in purchasing decisions after the digital payment system was introduced. Research conducted by Runnemark et al. (2015) found that people are willing to pay more for products via digital payment systems than with cash. We suggest that this is due to the representation of money, which leads to the salience of the physical form and the salience of the amount paid with the card. Alkhowaiter (2020) found that banks can focus on predictors on intentions to adopt such as performance expectations, effort expectations, social influence, trust and facilitate conditions of intention. This will help increase the rate of adoption of digital banking and payment methods. Consumers can ultimately put their trust in digital payment systems and make transactions easier; with trust and convenience, it is expected that buying interest will increase.

\section{Literature Review}

Our study is related to several research streams, with three topics most relevant to this paper: digital payments system analysis of buying decision. Payments are an economically fundamental area. A well-functioning payment system is a major precondition for financial stability and economic prosperity in a country, as it facilitates an efficient exchange of goods and services between consumers and businesses (Hanegraaf et al., 2020). Cash payment to determine optimal order quantity for the traditional EOQ model with a constant demand rate, assumed cash-on-delivery business transactions, and derived optimal order quantity and shelf space for perishable goods when demand is dependent on 
product freshness and displayed stocks (Chang et al., 2019). The provision of cash payments inevitably has negative effects such as capital opportunity costs and credit default risk that reduce the operational efficiency of firms and severely damage profitability (Wang et al., 2018). Taleizadeh (2014) studied how a gasoline supplier adopts an advance cash payment to improve profits.

The facilitation of digital payments is essential for the development of e-commerce within the European Union (Donnelly, 2016). The invention of the blockchain, the success of Bitcoin, its subsequent replication in a wide variety of other cryptocurrencies, and the proliferation of services to support them have attracted the interest of regulators, especially in the developed countries, where the oversight of the digital payment systems has progressed much more and is sophisticated (Papadopoulos, 2015). Digital payment solutions function as digital platforms that facilitate the direct interaction between multiple customer types affiliated with them (Staykova \& Damsgaard, 2015). Digital payment platforms are scalable with high development costs and low marginal costs (Staykova \& Damsgaard, 2015).

\section{Research Method}

The population used in this study is the Indonesian OVO payment application users who feel the difference between digital payment systems and cash payments. The OVO payment users recruited in studies were generally obtained through purposive sampling (characterized by the use of judgment and a deliberate effort to include presumably typical groups in the sample (Topp et al., 2004). This research uses descriptive quantitative research. To achieve this goal, quantitative descriptive analysis is used to determine the nature and intensity of the characteristics of buying interest perceived when a product is used (Cartier et al., 2006). Quantitative methods are especially important to explore the extent and variation of change (Smith \& Hasan, 2020).

To document the differences that occur in cash and digital payment systems in the buying decision, this study uses an paired T-test, and before conducting the test the data is processed using Kolmogorov Smirnov to determine the normality of the data used. Since the significance level is not violated when applying the independent samples F-test to data, which consist of positively-correlated pairs, and since the estimate of the variance is based on a larger number of 'degrees of freedom', the results suggest that when the sample size is small, one should not worry much about the possible existence of weak positive correlation (Pollak \& Cohen, 1981). This study also uses partially linear models to determine the effect of cash and digital payment systems on consumer buying interest behavior. Partially linear models are widely used in semi parametric models. They allow to more easily explain the effect of each variable and are more flexible than linear models (Liu et al., 2020).

Grading in this study uses a Likert scale to get quantitative data. Likert type vertical scale format is a visual distance that is usually covered by the rating scale: the endpoint in the horizontal Likert scale format is visually further apart from the midpoint compared to the vertical Likert scale format, where only the dashed lines represent different response categories (Weijters et al., 2020).

\section{Results}

The results of the first test are produced by testing the normality of the data using Kolmogorov Smirnov, normal data below the alpha value of 0.05 . From Table 2, it is evident that the data is normally distributed, so this research can be continued.

Based on Table 3, it appears that the value of cash payments generated by the F-test is significant and is evidenced by a very high F-Value, this is caused by consumer buying decision that is still accompanied by a cash payment system. So, cash payments are still a means of payment that is in great demand by the people of Indonesia. Indonesians still consider cash as a payment instrument that is easy to use, comfortable, durable, and safe from counterfeiting. Furthermore, the results of the digital payment F-test calculation show a lower value compared to cash payments, but this suggests that the development of digital services through the OVO Indonesia application is developing quickly, is comfortable, secure, and effective in conducting transactions, and is a priority for customers to be able to buy products easily.

Table 2: Normality Data

\begin{tabular}{|l|c|c|c|c|}
\hline \multirow{2}{*}{} & \multicolumn{4}{|c|}{ Kolmogorov Smirnov } \\
\cline { 2 - 5 } & Statistic & N & Significant & Information \\
\hline Cash payment & 0,181 & 30 & 0,013 & Normal \\
\hline Digital Payment & 0,269 & 30 & 0,001 & Normal \\
\hline Buying Interest & 0,218 & 30 & 0,000 & Normal \\
\hline
\end{tabular}


Table 3: Cash Payment and Digital Payment F-Test

\begin{tabular}{|l|c|c|c|}
\hline Variable & DF & F-Value & Significant \\
\hline Cash Payment & 29 & 99,563 & 0,000 \\
\hline Digital Payment & 29 & 60,967 & 0,000 \\
\hline
\end{tabular}

Table 4: Paired Sample Statistic

\begin{tabular}{|l|c|c|}
\hline Variable & Mean & Standard Deviation \\
\hline Cash Payment & 33,7333 & 3,67595 \\
\hline Digital Payment & 33,4667 & 4,76973 \\
\hline
\end{tabular}

Table 5: Paired Sample Test

\begin{tabular}{|l|c|c|c|c|}
\hline Paired & $\mathbf{t}$ & DF & Significant & Information \\
\hline $\begin{array}{l}\text { Cash -Digital } \\
\text { Payment }\end{array}$ & 0,718 & 29 & 0,478 & $\begin{array}{c}\text { There is no } \\
\text { difference }\end{array}$ \\
\hline
\end{tabular}

Table 6: Cash payment of buying interest behavior

\begin{tabular}{|l|c|c|c|c|}
\hline \multirow{2}{*}{ Variable } & \multicolumn{2}{|c|}{ Coefficient } & \multirow{2}{*}{ t-value } & \multirow{2}{*}{ Information } \\
\cline { 2 - 3 } & B & Beta & & \\
\hline Cash payment & 0,525 & 0,681 & 3,748 & Significant \\
\hline
\end{tabular}

Table 4 shows the descriptive statistical results from the sample studied in cash payments and digital payments. The mean value of the variable cash payment is 33.7333 , while the mean value of the digital variable is 33.44667 , with the respondent as big as 30 . With the mean value of cash payment $>$ Digital payment, descriptively there is no difference in consumer buying interest behavior resulting from the payment system cash or digital; to prove it again, researchers applied paired sample T-test.

Table 5 produces t-value $<$ t-table with a degree of freedom 29 of $0.718<1,699$, proving that the cash and digital payment systems do not affect buying interest behavior; cash and digital payment systems still need to be developed to be able to provide effectiveness and efficiency in trade transactions, this is also evidenced by the significant value greater than the alpha value of $0.05>0.478$.

Table 6 shows partial test results of cash payment variables on buying interest behavior t-value $>$ t-table with a significance value below 0.05 , which concludes that cash payments still affect buying interest behavior in Indonesia. Cash payments are still prevalent in Indonesia for micro and traditional trade transactions; according to data, $73 \%$ of micro trade transactions still use the cash payment system, for example in traditional markets, and to meet daily needs that still use the cash payment system as a transaction tool.
Table 7: Digital payment of buying interest behavior

\begin{tabular}{|l|c|c|c|c|}
\hline \multirow{2}{*}{ Variable } & \multicolumn{2}{|c|}{ Coefficient } & \multirow{2}{*}{ t-value } & \multirow{2}{*}{ Information } \\
\cline { 2 - 3 } & B & Beta & & \\
\hline Digital payment & 0,156 & 0,232 & 1,276 & Significant \\
\hline
\end{tabular}

Almost half of the national economy is supported by small industries and micro trade.

Table 7 shows partial test results of digital payment variables on the behavior of interest in buying t-value $<$ t-table with a significance value $>0.05$, concluding that digital payments have not much influenced buying interest behavior in Indonesia. OVO Indonesia's digital payments began to develop in 2016, and have continued to experience an upward trend in users since they began active transactions, especially based on mobile phone applications and websites. In a relatively short period of time OVO Indonesia already had 115 devices available in 303 cities in Indonesia. This development continues until today so it is predicted that someday the digital payment system will be able to influence consumer buying interest behavior in all transactions.

\section{Discussion}

The results of this research show that cash payment and digital payment systems have not significantly influenced consumers' buying decision. Cash payments are still very dominant in transactions in traditional markets and trade in small industrial products. Indonesia is a large country with a very productive population, almost half the population is engaged in transactions every day, and $73 \%$ take place in traditional markets. Research (Kim, 2020) reveals that, as the number of successful previous payments increases, the likelihood of default on current loans decreases; conversely, the default probability of a current loan increases as the number of previous defaults increases.

In addition, the high failure hazard ratio indicates that this ratio has a very significant impact on loan repayment performance. The digital payment system OVO Indonesia has just launched a digital-based payment system application in 2016, and over a relatively short period of time the company has been developing rapidly, as evidenced by providing application devices in 303 cities throughout Indonesia. The results of a comparative study of payment systems do not show an impact on consumer buying decision, but it is different when the research results are obtained with partially linear models. The results show that the cash payment system is still very dominant in influencing consumer buying decision, this is in line with research by paired T-test that shows the F-Value of cash payments is higher than the $\mathrm{F}$-value generated from a digital payment system. 


\section{Conclusion}

The first conclusion is that the cash and digital payment systems make no difference in influencing buying decision on all transactions, but the F-value shows a significant development of Indonesia's OVO digital payment system because of the convenience and guaranteed security. The constraints faced are the equipment, which is not yet fully available in all cities. Another advantage gained from digital payment systems compared to cash payments is time efficiency in carrying out transactions.

The second conclusion is that the cash payment system still retains a very high value in society, where daily needs in traditional markets are difficult to be met with digital payments because consumers prefer to make direct transactions face-to-face rather than ordering e-commerce products, besides that consumers prefer to hold direct product to be purchased to ensure the quality of the goods. Partially, the cash payment variable also has a significant impact on buying decision that is supported by t-value> t-table, this supports the results of research by testing the F-value with a large value affecting buying interest behavior. Cash payments are still more dominant because the platform network structure is not evenly distributed, plus there are still many regions that have limited Internet access. Digital payments are dominated in urban areas that have more equitable and stable Internet access, coupled with the behavior of urban people who spend more time working outside the home.

\section{References}

Alkhowaiter, W. A. (2020). Digital payment and banking adoption research in Gulf countries: A systematic literature review. International Journal of Information Management, 53, 102102. https://doi.org/10.1016/j.ijinfomgt.2020.102102

Arif, D., Yucha, N., Setiawan, S., Oktarina, D., Martah, V., \& Muttaqiin, N. (2020). Applications of Goods Mutation Control Form in Accounting Information System: A Case Study in Sumber Indah Perkasa Manufacturing, Indonesia. Journal of Asian Finance, Economics and Business, 7(8), 419-424. https:// doi.org/10.13106/jafeb.2020.vol7.no8.419

Cao, K., Han, G., Xu, B., \& Wang, J. (2020). Gift card payment or cash payment: Which payment is suitable for trade-in rebate? Transportation Research Part E: Logistics and Transportation Review, 134, 101857. https://doi.org/10.1016/j.tre.2020.101857

Cartier, R., Rytz, A., Lecomte, A., Poblete, F., Krystlik, J., Belin, E., \& Martin, N. (2006). Sorting procedure as an alternative to quantitative descriptive analysis to obtain a product sensory map. Food Quality and Preference, 17(7-8), 562-571. https:// doi.org/10.1016/j.foodqual.2006.03.020

Chang, C., Ouyang, L., Teng, J., \& Lai, K. (2019). Manufacturer's pricing and lot-sizing decisions for perishable goods under various payment terms by a discounted cash flow analysis.
International Journal of Production Economics, 218, 83-95. https://doi.org/10.1016/j.ijpe.2019.04.039

Donnelly, M. (2016). Payments in the digital market: Evaluating the contribution of Payment Services Directive II. Computer Law and Security Review, 32(6), 827-839. https://doi.org/10.1016/j. clsr.2016.07.003

Eitzel, M. V., Mhike Hove, E., Solera, J., Madzoro, S., Changarara, A., Ndlovu, D., Chirindira, A., Ndlovu, A., Gwatipedza, S., Mhizha, M., \& Ndlovu, M. (2018). Sustainable development as successful technology transfer: Empowerment through teaching, learning, and using digital participatory mapping techniques in Mazvihwa, Zimbabwe. Development Engineering, 3, 196-208. https://doi.org/10.1016/j.deveng.2018.07.001

Grüschow, R. M., Kemper, J., \& Brettel, M. (2016). How do different payment methods deliver cost and credit efficiency in electronic commerce? Electronic Commerce Research and Applications, 18, 27-36. https://doi.org/10.1016/j.elerap.2016.06.001

Halik, A., Arif, D., Ekasari, R., Yucha, N., \& Pramudita, R. A. (2020). Economic Impacts of COVID-2019 and its Implications on e-Commerce Buying Interest: A Case Study in Shopee Online-shop. International Journal of Advanced Science and Technology, 29(4), 2530-2538. http://sersc.org/journals/index. php/IJAST/article/view/21093

Hanegraaf, R., Larçin, A., Jonker, N., Mandley, S., \& Miedema, J. (2020). Life cycle assessment of cash payments in the Netherlands. International Journal of Life Cycle Assessment, 25(1), 120-140. https://doi.org/10.1007/s11367-019-01637-3

Kim, D. (2020). The Importance of a Borrower's Track Record on Repayment Performance: Evidence in P2P Lending Market. Journal of Asian Finance, Economics and Business, 7(7), 85-93. https://doi.org/10.13106/jafeb.2020.vol7.no7.085

Liu, Y., Zhang, S., Ma, S., \& Zhang, Q. (2020). Tests for regression coefficients in high dimensional partially linear models. Statistics and Probability Letters, 163, 108772. https://doi. org/10.1016/j.spl.2020.108772

Milian, E. Z., Spinola, M. de M., \& Carvalho, M. M. d. (2019). Fintechs: A literature review and research agenda. Electronic Commerce Research and Applications, 34(January). https://doi. org/10.1016/j.elerap.2019.100833

Nguyen, D. D., Dinh, H. C., \& Nguyen, D. V. (2020). Promotion of Fintech Application for the Modernization of Banking-Finance System in Vietnam. Journal of Asian Finance, Economics and Business, 7(6), 127-131. https://doi.org/10.13106/jafeb.2020. vol7.no6.127

Palmié, M., Wincent, J., Parida, V., \& Caglar, U. (2020). The evolution of the financial technology ecosystem: An introduction and agenda for future research on disruptive innovations in ecosystems. Technological Forecasting and Social Change, 151, 119779. https://doi.org/10.1016/j.techfore.2019.119779

Papadopoulos, G. (2015). Blockchain and Digital Payments: An Institutionalist Analysis of Cryptocurrencies. In: Handbook of Digital Currency: Bitcoin, Innovation, Financial Instruments, and Big Data. Amsterdam, The Netherlands: Elsevier Inc. https://doi.org/10.1016/B978-0-12-802117-0.00007-2 
Patil, P., Tamilmani, K., Rana, N. P., \& Raghavan, V. (2020). Understanding consumer adoption of mobile payment in India: Extending Meta-UTAUT model with personal innovativeness, anxiety, trust, and grievance redressal. International Journal of Information Management, 54(February), 102144. https://doi. org/10.1016/j.ijinfomgt.2020.102144

Pollak, M., \& Cohen, J. (1981). A comparison of the independentsamples t-test and the paired-samples t-test when the observations are nonnegatively correlated pairs. Journal of Statistical Planning and Inference, 5(2), 133-146. https://doi. org/10.1016/0378-3758(81)90023-9

Puspitasari, L., \& Ishii, K. (2016). Digital divides and mobile Internet in Indonesia: Impact of smartphones. Telematics and Informatics, 33(2), 472-483. https://doi.org/10.1016/j. tele.2015.11.001

Runnemark, E., Hedman, J., \& Xiao, X. (2015). Do consumers pay more using debit cards than cash? Electronic Commerce Research and Applications, 14(5), 285-291. https://doi. org/10.1016/j.elerap.2015.03.002

Smith, J. D., \& Hasan, M. (2020). Quantitative approaches for the evaluation of implementation research studies. Psychiatry Research, 283(March), 112521. https://doi.org/10.1016/j. psychres.2019.112521
Staykova, K. S., \& Damsgaard, J. (2015). The race to dominate the mobile payments platform: Entry and expansion strategies. Electronic Commerce Research and Applications, 14(5), 319-330. https://doi.org/10.1016/j.elerap.2015.03.004

Taleizadeh, A. A. (2014). An EOQ model with partial backordering and advance payments for an evaporating item. International Journal of Production Economics, 155(2006), 185-193. https:// doi.org/10.1016/j.ijpe.2014.01.023

Topp, L., Barker, B., \& Degenhardt, L. (2004). The external validity of results derived from ecstasy users recruited using purposive sampling strategies. Drug and Alcohol Dependence, 73(1), 33-40. https://doi.org/10.1016/j.drugalcdep.2003.09.001

Wang, K., Zhao, R., \& Chen, H. (2018). Optimal credit period and green consumption policies with cash-credit payments under asymmetric information. Journal of Cleaner Production, 205, 706-720. https://doi.org/10.1016/j.jclepro.2018.09.081

Weijters, B., Millet, K., \& Cabooter, E. (2020). Extremity in horizontal and vertical Likert scale format responses. Some evidence on how visual distance between response categories influences extreme responding. International Journal of Research in Marketing. [In Press] https://doi.org/10.1016/j. ijresmar.2020.04.002 